Available online on 15.09.2017 at http://ujpr.org
Universal Journal of Pharmaceutical Research
An International Peer Reviewed Journal
Open access to Pharmaceutical research

\title{
LEAD ACETATE: A DANGEROUS ENVIRONMENTAL TOXICANT THAT IS AMELIORATED BY THE AQUEOUS EXTRACT OF FICUS VOGELII (FV) UCHEWA Obinna $O^{1}\left(\mathbb{D}\right.$, Okafor Samuel $O^{2}\left(D\right.$, NWAFOR Joseph $A^{1}(P$ \\ ${ }^{I}$ Department of Anatomy, Faculty of Basic Medical Sciences, Federal, University Ndufu-Alike Ikwo (FUNAI), Ebonyi State, Nigeria. \\ 2 Department of Anatomy, Faculty of Basic Medical Sciences, Ebonyi State, University (EBSU), Abakaliki, Ebonyi State, Nigeria.
}

\section{ABSTRACT}

Objectives: The aim of the present study was to investigate the effects of lead toxicity on the histoarchiteture of the vagina and cervix of adult female Wistar rats and the currative role of Ficus vogelii $(\mathrm{Fv})$ in lead toxicity.

Methods: The experiment lasted for a period of 21 days involving 20 adult female albino Wistar rats with an average weight of $145 \mathrm{~g}$. The rats were divided into five (5) groups A, B, C, D and E. A is negative control group that received normal saline, B is positive group that received lead acetate solution, C received Aqueous extract of $F v(100 \mathrm{~g} / \mathrm{kg})$ and lead acetate solution, D received aqueous extract of $F v(300 \mathrm{~g} / \mathrm{kg})$ and lead acetate solution group while E received aqueous extract of $F v$ only.

Results: Examination of the vagina and cervix histologically revealed various damages such as, necrosis, oedema and reduction is size suspected to be as a result of lead toxicity. These changes were ameliorated by the administration of $F v$ extract. Exposure to lead also produced significant reduction in blood supply to the vagina and cervix which caused the mucosa to necrotize. These structural changes correlated with the level of exposure in the vagina. They were mainly oedema, necrosis and denudation of the vaginal walls. These alterations can make the vagina and cervix acidic which have been implicated as one of the cause of infertility in females.

Conclusion: The results of this study suggested that treatment with $F$. vogelii has an ameliorative effect.

Keywords: Ameliorate, cervix, Ficus vogelii, lead, vagina.

Article Info: Received 2 July 2017; Revised 6 August; Accepted 5 September, Available online 15 September 2017

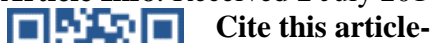

UCHEWA, Obinna O, Okafor Samuel O, NWAFOR Joseph A. Lead acetate: a dangerous environmental toxicant that is ameliorated by the aqueous extract of Ficus vogelii $(F v)$. Universal Journal of Pharmaceutical Research 2017; 2(4): 1-5.

DOI: http://doi.org/10.22270/ujpr.v2i4.R1

Address for Correspondence

UCHEWA Obinna O, Department of Anatomy, Faculty of Basic Medical Sciences, Federal, University Ndufu-Alike Ikwo (FUNAI), Ebonyi State, Nigeria, Tel: +2348172628746, E-mail: euchewal @ gmail.com

\section{INTRODUCTION}

Toxicity is very deadly to various part of human body which adversely affects the reproductive system leading to impaired reproduction ${ }^{22}$. It has been reported that the female reproductive system's functions in vitro can be modified by exposure to a very low level of $\mathrm{lead}^{1,6}$. Longer and more variable menstrual cycles have been found in lead treated female Rhesus monkeys ${ }^{12}$. The vagina is an important organ of reproduction in the female. It is also referred to as birth canal where the fetus passes during birth. Its importance in reproduction cannot be over emphasized especially to women. The Semen is deposited in the vaginal vault during intercourse and the spermatozoa make their way into the external os of the cervical canal, pass through the cervical canal into the uterine cavity, and then continue through the uterine cavity into the uterine tubes where fertilization occurs in the ampulla $^{3,20}$. This led us to examine the effect of lead acetate on the vaginal wall female Wistar rats. The extent of natural fertility that takes place is invariably connected to the motility of the spermatozoa and one of the things that affect sperm motility is vaginal toxicity (acidity). The toxicity of the vagina which can affect its histoarchiteture also causes the death of the spermatozoa and thereby impedes the fertility. The cervix is a narrow and cylindrical part of the uterus which communicates with the uterine body via the internal os and opens into the vagina at the external $\mathrm{os}^{3,21}$. During the movement of the spermatozoa, it moves from the vagina into the cervix and so anything that affects the histology of the cervix likely to alter the structure of the cervical mucus which protects the sperm from naturally acidic environment of the vagina and get it safely to the ovum. It has been noted that animals have protective mechanism in the form of 
antioxidant nutrients ${ }^{25}$, vitamins and several enzymes. Antioxidant may play an important role in abating some hazardous effects of lead ${ }^{6}$. This study seeks to assess the lead acetate induced histological damages on vagina and cervix; and to ascertain the protective effects of aqueous extract $F$. vogelii on female Wistar rats as an experimental model.

\section{MATERIALS AND METHODS}

Collection and authentication of plant materials

The leaves of $F$. vogelii was collected from Enyibichiri Ndufu-Alike Ikwo a town where Federal University Ndufu-Alike Ikwo (FUNAI) is located in Ikwo Local Government Area of Ebonyi State and authenticated in Botany Department of the University of Nigeria Nsukka (UNN).

\section{Preparation of the extracts}

Those leaves were washed and dried in ventilated room and thereafter, were crushed into powder using pestle and mortar, and passed through mesh sieve to get the fine powders. The powdered form was soaked in water for $48 \mathrm{~h}$ and filtered using a white muslin cloth to remove debris and then re-filtered with filter paper to obtain a homogenous clear filtrate which was concentrated in vacuo, using a rotary evaporator at $<40^{\circ} \mathrm{C}$ to yield a sticky paste ${ }^{16}$. This was stored under refrigeration until it was required. All preparations were performed at the Department of Anatomy Faculty of Basic Medical Sciences, Federal University NdufuAlike, Ikwo (FUNAI), Ebonyi State, Nigeria. Animal procurement and housing

Twenty (20) adult female Wistar rats with average weight of $145 \mathrm{~g}$ were procured from the animal house of the Department of Pharmacology, University of Nigeria Enugu Campus (UNEC) and maintained in the Animal House of Anatomy Department of Faculty of Basic Medical Sciences of the same University.

The animals were housed in netted cages, fed with grower's mash and allowed water ad libitum with acclimatization period of one week (7 days).

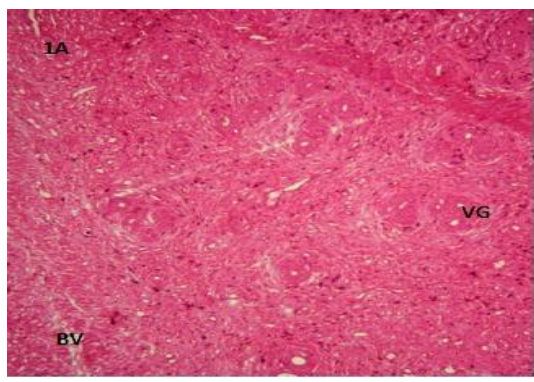

1(A)

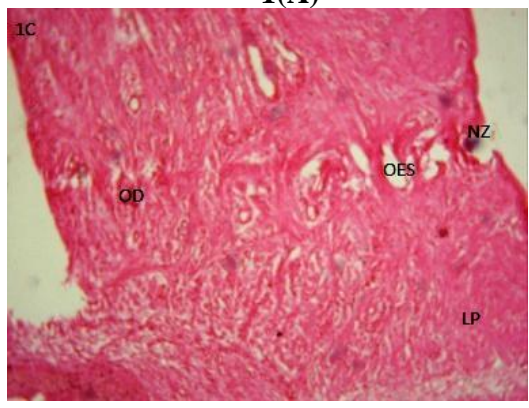

$\mathbf{1}(\mathbf{C})$

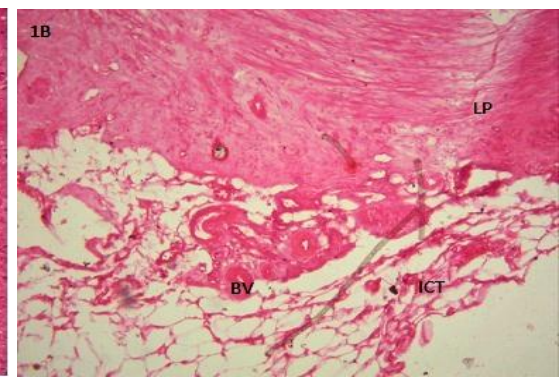

1(B)

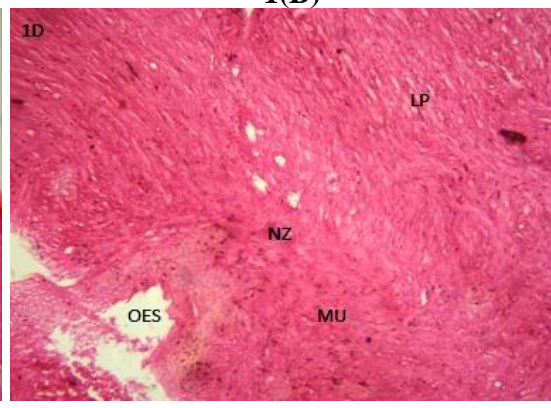

1(D)

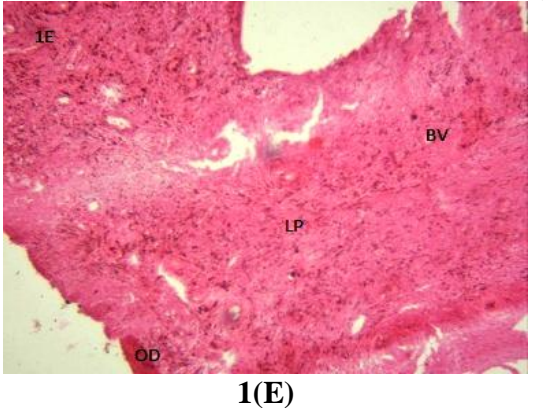

Figure 1: (A). Vagina from group A (negative control) revealed the presence of a normal mucosa, BV-Blood vessel and VGVagina gland. 1(B). Vagina following administration of lead acetate $(1.5 \mathrm{mg} / \mathrm{kg})$ for 14 days. BV-Blood vessel, FC-Fatty change, ICT-Interconnective tissue and LP-Lamina propria. H and E stains, 200X. 1(C): Vagina following administration of lead acetate $(1.5 \mathrm{mg} / \mathrm{kg})$ for 7 days and 24 hours later exposed to aqueous extract of $F$. vogelii $(100 \mathrm{~g} / \mathrm{kg})$ for another 7 days. OD-Oedema, LP-

Lamina propria, OES-Optically empty space and NZ-Necrotic zone. 1(D): Vagina following administration of lead acetate $(1.5 \mathrm{mg} / \mathrm{kg})$ for 7 days and 24 hours later exposed to aqueous extract of $F$. vogelii $(300 \mathrm{~g} / \mathrm{kg})$ for another 7 days. OES-Optically

Empty Space, MU-Muscle, NZ-Necrotic zone and LP-Lamina propria. H and E stains, 200X. 1(E). Vagina following administration of aqueous extract of $F$. vogelii $(300 \mathrm{~g} / \mathrm{kg}$ ) for another 14 days. OD-Oedema, LP-Lamina propria, and BV-Blood vessel. (H and E stains, 200X.) 


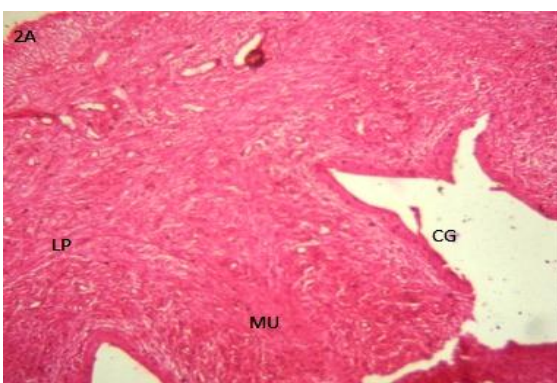

2(A)

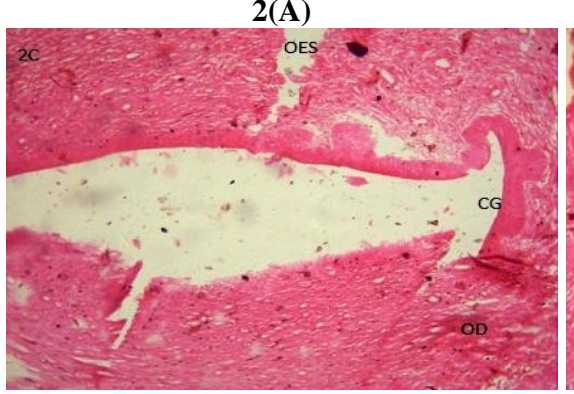

2(C)

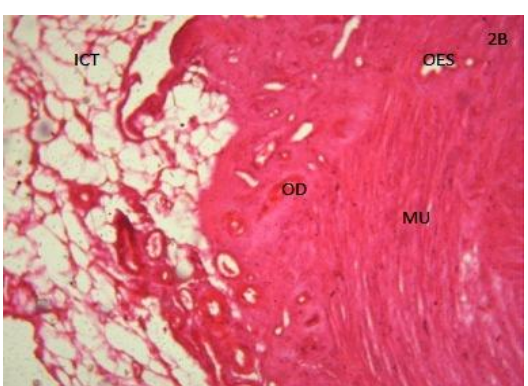

2(B)

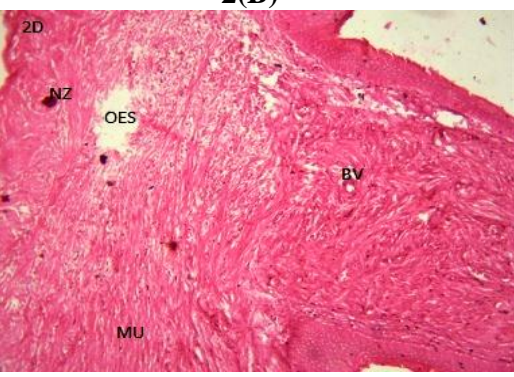

2(D)

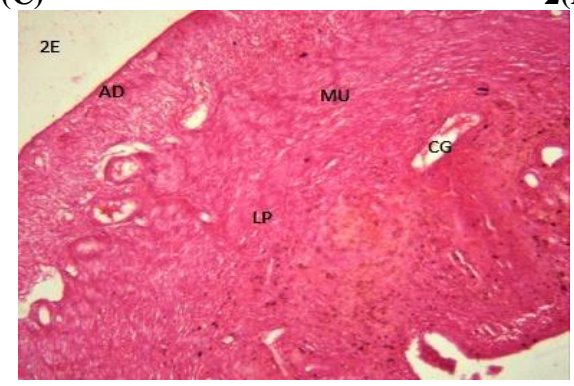

2(E)

Figure: 2(A). The cervix of group A (negative control) revealed the presence of a normal mucosa, LP-Lamina propria and CG-

Cervical gland. 2(B). Cervix following administration of lead acetate $(1.5 \mathrm{mg} / \mathrm{kg})$ for 14 days.

OD-Oedema, FC-Fatty change, ICT-Interconnective tissue, MU-Muscle and OES-Optically Empty Space. H and E stains, 200X. 2(C). Cervix following administration of lead acetate $(1.5 \mathrm{mg} / \mathrm{kg}$ ) for 7 days and 24 hours later exposed to aqueous extract of $F$. vogelii $(100 \mathrm{~g} / \mathrm{kg}$ ) for another 7 days. OD-Oedema, CG-Cervical gland and OES-Optically Empty Space. 2(D).Cervix following administration of lead acetate $(1.5 \mathrm{mg} / \mathrm{kg}$ ) for 7 days and 24 hours later exposed to aqueous extract of $F$. vogelii $(300 \mathrm{~g} / \mathrm{kg})$ for another 7 days. OES-Optically Empty Space, MU-Muscle, NZ-Necrotic zone and Bv-Blood vessel. H and E stains, 200X.

2(E). Cervix following administration of aqueous extract of $F$. vogelii $(300 \mathrm{~g} / \mathrm{kg})$ for another 14 days

MU-Muscle, CG-Cervical gland, LP-Lamina propria, and AD-adventitia. (H and E stains, 200X).

\section{Animal grouping and experimental design}

The rats used in this experiment were randomly assigned into five groups as follow: A, B, C, D and E containing four (4) animals per group.

Group A-Control Group (negative): The rats of this group received standard rat's diet containing $0.5 \%$ $\mathrm{NaCl}, 22 \%$ protein and $4-6 \%$ dietary fat and tap water ad libitum.

Group B: Lead acetate solution (positive control): The rats in this group received $1.5 \mathrm{mg} / \mathrm{kg}$ of Lead acetate solution daily for 14days.

Group C: Lead acetate solution and aqueous $F$. vogelii extract (lower dose): The rats in this group received lead acetate $(1.5 \mathrm{mg} / \mathrm{kg})$ for 7 days and 24 hours later exposed to aqueous extract of $F$. vogelii $(100 \mathrm{~g} / \mathrm{kg})$ till the end of experiment. The dosage was calculated based on the rats' weight.

Group D: Lead acetate solution and aqueous $F$. vogelii extract (higher dose): The rats in this group received lead acetate $(1.5 \mathrm{mg} / \mathrm{kg})$ for 7 days and 24 hours later exposed to aqueous extract of $F$. vogelii $(300 \mathrm{~g} / \mathrm{kg})$ till the end of experiment. The dosage was calculated based on the rats' weight.
Group E: Aqueous extract of $\boldsymbol{F}$. vogelii only: The rats in this group received $300 \mathrm{mg} / \mathrm{kg}$ of aqueous extract of F.vogelii only daily for 14days.

NOTE: The extracts and lead acetate solution were administered by oral intubation using oral gavage (cannula). The experiment lasted for a period of 21 days.

\section{Histological study}

At the end of the experiment, the rats were starved overnight and anaesthetized with chloroform and then decapitated $^{17}$. The animals were dissected, and the vagina and cervix were quickly harvested and fixed in bouin's fluid for routine histological procedures. The tissue was processed and embedded in paraffin wax. Thin sections $(5-6 \mu \mathrm{m})$ were obtained and stained using haematoxylin and eosin ( $\mathrm{H}$ and $\mathrm{E})$ and were examined under light microscope to determine the histological changes that occurred.

\section{RESULTS}

The results of the histological studies carried out in adult female Wistar rats' vagina and cervix at the end 
of 21 days are presented in the figures below as histological slides.

\section{The vagina}

When the vagina was microscopically examined, the negative control and extract group revealed the presence of a normal structure of vaginal mucosa and glands with no alterations (Figure $1 \mathrm{~A}$ and Figure 1E). Following exposure to $1.5 \mathrm{mg} / \mathrm{kg}$ lead acetate (positive control), some areas of the vagina presented optically empty spaces in the tissue, as well as diffuse oedemas and vaginal wall denudation (Figure 1B), necrotic zones, diffused oedemas and vaginal glands necrosis were also visibly present. After the animals were treated with the extract of $\mathrm{Fv}$, there were signs of recovery revealed by the vagina. This is presented in Figures 1C and Figure 1D.

\section{The cervix}

The microscopic examination of the negative control and extract group revealed the presence of a normal structure of uterine cervix mucosa and glands with no alterations (Figures 2A and 2E). as the animals were exposed to $1.5 \mathrm{mg} / \mathrm{kg}$ lead acetate (positive control), some areas of the cervix presented optically empty spaces, as well as diffuse oedemas and cervical wall denudation (Figure 2B), necrotic zones, and cervical glands necrosis were also visibly. Following the administration of the aqueous extract of $F$. vogelii, the cervix showed signs of recovery as presented in Figure $2 \mathrm{C}$ and $2 \mathrm{D}$.

\section{DISCUSSION}

Most researches on female specimens' exposure to lead has focused on clinically visible effects such as miscarriage, premature delivery, and infant mortality in humans and animals ${ }^{24}$ and effects of lead on the fallopian tubes, ovaries and uterus ${ }^{4,5} . F$. vogelii is a vegetable that is locally used to treat some illnesses and have also been implicated by so many researchers as an herbal remedy for some human diseases ${ }^{7,9,10}$. Works on vaginal and cervical toxicity are sparse, yet many authors have identified the toxic effects of lead on the uterus, fallopian tube and ovaries and went ahead to prove that it can hamper reproduction ${ }^{14,19,24}$. In this study, we noticed that all the histology of the organs and tissues under investigation were seriously altered. This caused changes in the reproductive system integrity leading to their deformations. These changes in the vagina make it toxic and increase its acidity making the environment dangerous for the survival of sperm. The major structural changes as found in the vagina were diffuse edema, necrosis in the vagina and cervix, optical empty spaces, denudation of the vaginal and cervical mucosa, and vaginal and cervical gland necrosis as shown in the figures above. The administration of the extract appeared to neutralize the effects of lead on the organs. The fatty change that appeared in the vagina with the oedema disappeared following the administration of the extract as seen in figures $1 \mathrm{C}$ and $1 \mathrm{D}$. The main changes in the cervix are diffuse oedema, cervical gland necrosis, optical empty spaces, denudation of the cervical mucosa, and cervical gland necrosis. There was restoration of the muscle and mucosa integrity of the cervix following the administration of the extract of F.vogelii. It can be noted that the effects of lead on reproductive systems are complex and sex-specific, and they seem to involve multiple locations on the hypothalamic-pituitarygonadal axis, confirming our findings on female rats. Women's occupational exposure to lead is undoubtedly related to reproductive impairments ${ }^{23}$.

Most impairments in the nervous system, the kidneys, the reproductive system and every other parts of the body as reported in other literatures show the importance and versatility of lead effects in mammals ${ }^{2,8,11,13,14,15,18}$.The structural alterations as noticed in the present study in the vagina and cervix adult rats have been able to demonstrate the poisonous effects of lead on the vagina and cervix. With the alterations of the cervical walls, the secretion of cervical mucus that helps the sperm's move towards the egg will be hampered seriously this in turn leads to infertility in female. With the results of this research, we wish to recommend the use of this leave Ficus vogelii as vegetable for families and its inclusion as an herbal medicine for the treatment of reproductive toxicity especially that of lead toxicity in the female laboratory animals.

\section{AUTHOR'S CONTRIBUTION}

The manuscript was carried out, written, and approved in collaboration with all authors.

\section{ACKNOWLEDGEMENTS}

The authors extend their thanks and appreciation to the University Ndufu-Alike Ikwo (FUNAI), Ebonyi State, Nigeria to provide necessary facilities for this work.

\section{CONFLICT OF INTEREST}

No conflict of interest is associated with this work.

\section{REFERENCES}

1. Avazeri, N. Denys, A. Lefèvre, B. Lead Cations affect the Control of both Meiosis arrest and Meiosis Resumption of the Mouse oocyte in vitro at least via the PKC pathway. Biochimie 2006; 88(11); 1823-1829. https://doi.org/10.1016/j.biochi.2006.04.011

2. Borja-Aburto VH, Hertz-Picciotto I, Rojas-Lopez MR, Farias P, Rios C, Blanco J. Blood lead levels measured prospectively and risk of Spontaneous Abortion. Am J Epidemiol 1999; 18: 590-597. https://doi.org/10.1093/oxfordjournals.aje.a010057

3. Drake R., Vogl W, Mitchell AWM. Grays Anatomy for Students. 3rd eds. Chpt, Churchill Livingstone (Elsevier's) Publishers; Saunders. 2014; 5: 397-416.

4. Dumitrescu E, Chiurciu V, Muselin F, Popescu R, Brezovan D, Cristina RT. Effects of Long-term Exposure of Female Rats to Low Levels of Lead: Ovary and Uterus Histological Architecture Changes. Turk J Biol 2015; 39: 284-289.https://doi.org/10.3906/biy-1407-6

5. Dumitrescu E; Cristina RT; and Muselin F. Reproductive Biology Study of dynamics of Female Sexual hormones: a 12-months exposure to lead acetate Rat model. Turk J Biol 2014; 38: 581-585.https://doi.org/10.3906/biy-1402-50

6. Durgesh NS, Lata B. Role of Vitamin E on Anti folliculogenesis effects of lead acetate on diameter of follicles containing ovarian tissue of Swiss albino mice; Glob J Bio Agri Health Sci 2014; 3(1):322-325.

7. Egbuna PAC, Joshua PE, Chigbo MU. Antihepatotoxic effects of Ficus Vogelii ethanol leaf extract on the liver 
function indices of $\mathrm{Ccl}_{4}$-Induced Hepatotoxicity in Rats: $\mathrm{J}$ American Sci 2011; 7(6): 28-34.

8. Hilderbrand DC, Der R, Griffin WT, Fahim MS. Effect of lead acetate on Reproduction. Am J Obstet Gynecol 1973; 115: $1058-1065$ https://doi.org/10.1016/0002-9378(73)90554-1

9. Igile GO, Utin IC, Iwara IA, B.I.A. Mgbeje BIA, Ebong PE. Ethanolic extract of Ficus vogelii ameliorates dyslipidemia in diabetic albino wistar rats. Int J Curr Res Biosci Plant Biol 2015; 2(8):87-96.

10. Igile GO, Isika AI, Essiet GA, Iwara IA, Mgbeje BIA, Ebong PE. Antihypertensive and electrolyte modulatory potential of vernonioside E (steroidal saponin) from Vernonia amygdalina (Asteraceae) in adult Wistar rats. Planta Med. 2015. https://doi.org/10.1271/bbb.56.845

11. Junaid M, Chowdhuri DK, Narayan R, Shanker R, Saxena DK. Lead induced changes in ovarian follicular development and maturation in mice. J Toxicol Env Health 1997; 50: 31-40. https://doi.org/10.1080/009841097160582

12. Laughlin NK, Bowman RE, Franks PA, Dierschke DJ. Altered menstrual cycles in Rhesus monkeys induced by lead. Fundam App Toxicol 1987; 9(4); 722-729. https://doi.org/10.1016/0272-0590(87)90179-5

13. Nampoothiri LP, Gupta S. Simultaneous effect of lead and cadmium on granulosa cells: a cellular model for ovarian toxicity. Reprod Toxicol 2006; 21: 179-185. https://doi.org/10.1016/j.reprotox.2005.07.010

14. Piasek M, Kostial K. Reversibility of the effects of lead on the reproductive performance of female rats. Reprod Toxicol 1991; 5:45-51.PMID: 24917923

15. Saritha S, Reddy PS, Reddy GR. Partial recovery of suppressed reproduction by Withania somnifera Dunal in female rats following perinatal lead exposure. Int J Green Pharm 2011; 5: 121-125.

16. Sasidharan S, Chen Y, Saravanan D, Sundram K M, Yoga LL. Extraction, Isolation and Characterization of
Bioactive Compounds from Plants' Extracts. Afr J Tradit Complement Altern Med 2011; 8(1):1-10.PMID: 22238476

17. Schoenwolf GC, Bleyl SB, Brauer PR, Francis-west PH, Philipa H. Larsen's Human Embryology (5thedn). New York; Endinburgh: Churchill Livingstone chapter 16. 2015.

18. Shah A, Mian M, Khan S, Tayyab M, Chaudary N, Ahmed $\mathrm{N}$. Correlation of blood lead levels with atresia of ovarian follicles of albino mice. Ann Pak Inst Med Sci 2008; 4:188-192.

19. Silberstein T, Saphier O, Paz-Tal O, Trimarchi JR, Gonzales L, Keefe DL. Lead concentrates in ovarian follicle compromises pregnancy. J Trace Elem Med Biol 2006; 220: 205-207.

https://doi.org/10.1016/j.jtemb.2006.05.001

20. Snell RS. Clinical Anatomy by regions, Lippincott, Williams and Wilkins, London. 2012, Chapter 7: 279-297.

21. Standring S, Ellis H, Healy JC, Johnson D, Williams, A, Collins P. Gray's Anatomy: the Anatomical Basis of Clinical Practice. 40th edition: Madrid Churchill Livingstone. 2008; Chapter 77, 1530-1720.

22. Sullivan FM. Impacts of the Environment on Reproduction from Conception to Parturition. Env. Health Perspec 1993; 101(Suppl 2):13-18.

https://doi.org/10.1289\%2Fehp.93101s213

23. Tang N, Zhu ZQ. Adverse reproductive effects in female workers of lead battery plants. Int J Occup Med Env 2003; 16: 359-361.https://doi.org/10.12669\%2Fpjms.314.7066

24. Taupeau C, Poupon J, Nomé F, Lefèvre B. Lead accumulation in the mouse ovary after Treatment-Induced Follicular Atresia. Reprod Toxicol 2001; 15(4), 385-391. https://doi.org/10.1016/S0890-6238(01)00139-3

25. Young Barbara, James S Lowe, Alan Stevens, John O. Heath. Weathers functional Histology A text and colour atlas $6^{\text {th }}$ edition. Churchhill Livingstone. 2013; Chapter 19, 362-375. 